\title{
Effect of steel fibers over the Self Compacting Concrete
}

\author{
A. Chithambar Ganesh, M. Muthukannan
}

\begin{abstract}
The introduction of self-compacting concrete in the construction industry overcomes the flaws caused due to the improper compaction of concrete. Fibers are proved to increase the properties of conventional concrete. This research focuses on the performance of self-compacting concrete after augmenting steel fibers. The steel fibers are added in proportions such as 0.25 percentage, 0.5 percentage, 0.75 percentage and 1 percentage. After casting the self- compacting concrete, the strength was assessed for 7 days and 28 days and its compressive strength and split tensile strength was analyzed. The inclusion of steel fibers yielded good outcome in the tests and it is proved to yield better engineering properties.
\end{abstract}

\section{INTRODUCTION} of concrete that spreads easily without any assistance of vibrators. SCC is non-segregating concrete that is placed by means of its own weight and between bars without any detachment [1]. SCC was given by Hajime Okamura in the 1980 to overcome the problems arising due to inadequate compaction of the conventional concrete and to have proper compaction the $[2,3]$. Due to its highly out-flowable nature it can it spreads uniformly around the reinforcements without any segregation. The advantage of using Self Compacting concrete are the minimal material cost, reduced construction time and labor cost, It eliminates the need for vibration, facilitates constructability and ensures good structural performance [4-7]. Due to high fluidity, it spreads uniformly during the placing process, pouring of concrete is effortless and can be pumped through longer distance [8]. The SCC has more amount of fineness and reduces the water cement ratio [2]. Fibers are added to the concrete to enhance the engineering properties of concrete. In general there are two types of fibers added to the concrete like natural and synthetic fibers. Among many available fibers, polypropylene, glass, steel were found to enhance the engineering properties of conventional concrete. The incorporation of steel fibers reduces the brittleness of conventional concrete and increases its ductility. Utilization of steel fibers increases the flexural strength of the concrete and the values increases from $10 \%-30 \%$ depending upon the proportion of fiber added to concrete [9]. Many research works suggest that utilization of fibers is beneficial for other concretes like Geopolymer concrete [10]. Hence in this study, an accession was made to review the performance of fiber added self - compacting concrete. Sufficient care was taken to ensure that flow ability of concrete was under standards.

Revised Manuscript Received on December 30, 2019.

A. Chithambar Ganesh, Assistant Professor, Department of Civil Engineering, Kalasalingam University, chithambarmailid@gmail.com

Dr. M. Muthukannan,Professor, Department of Civil Engineering,Kalasalingam University, civilkannan@gmail.com
Self -Compacting Concrete is a highly out-flowable type

Steel fiber is used in this work as it was found to reduce the crack formation, shrinkage and creep. At initial stage, flowability, passing ability test were carried out in the SCC. After confirming its standards to be the self compacting concrete, further investigations were carried out to determine its compressive strength and split tensile strength at for 7 days and 28 days.

\section{MATERIALS}

\subsection{FINE AGGREGATE:}

Aggregates passing through $4.75 \mathrm{~mm}$ sieve was taken and its physical properties were determined.

\subsection{COARSE AGGREGATE:}

Aggregates in the size of $20 \mathrm{~mm}$ was taken and its physical properties were determined.

\subsection{CEMENT}

Ordinary Portland Cement of 43 Grade was used and its physical properties are listed below.

TABLE 1 PHYSICAL PROPERTIES OF OPC

\begin{tabular}{|c|l|l|}
\hline S.No & Physical Properties & Results obtained \\
\hline 1. & Specific Gravity & 3.15 \\
\hline 2. & Fineness test & $5 \%$ \\
\hline 3. & Normal Consistency & $34 \%$ \\
\hline
\end{tabular}

\subsection{STEEL FIBRES:}

Hooked steel fibers are of a length $35 \mathrm{~mm}$, a diameter $0.50 \mathrm{~mm}$ was used as the reinforcing material for concrete.

\subsection{WATER:}

Ordinary portable water was used. The properties of water are tabulated in Table2.

TABLE 2 PHYSICAL PROPERTIES OF WATER

\begin{tabular}{|l|l|l|}
\hline S.No & Tests & Results obtained \\
\hline 1. & $\mathrm{pH}$ & 7.18 \\
\hline 2. & Hardness & $275 \mathrm{mg} / \mathrm{l}$ of $\mathrm{CaCO}_{3}$ \\
\hline
\end{tabular}

\subsection{DESIGN}

Mix design of the self-compacting concrete was:

Cement $=382 \mathrm{~kg} / \mathrm{m} 3$, silica fume $=18: 5 \mathrm{~kg} / \mathrm{m} 3$, natural sand $(0-8 \mathrm{~mm})=1180 \mathrm{~kg} / \mathrm{m} 3$, crushed stone $(9-18 \mathrm{~mm})=560$ $\mathrm{kg} / \mathrm{m} 3$. During the mix, the fine aggregate and course aggregate were in the saturated surface dry condition and the steel fibers were gradually added to the specimen. Water cement ratio of the mix was 0.505 . The fiber volume ratio was $0.4 \%$, corresponding to $50 \mathrm{~kg} / \mathrm{m} 3$.

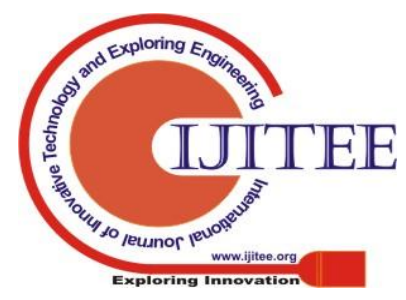


The fiber length and the fiber diameter were $35 \mathrm{~mm}$ and $0.5 \mathrm{~mm}$, respectively. Density of the steel fibers was 7860 $\mathrm{kg} / \mathrm{m} 3$. Three different ratios of steel fiber were employed in the experiment.

\section{EXPERIMENTAL PROGRAM}

Various ingredients were proportioned based on the mix design and was mixed on an absorbing platform through manual mixing. All the ingredients were thoroughly mixed and the mixing was done systematically. During the preparation of the specimen steel fibers should be added before the inclusion of cement. And the assessment was done for 7 days and 28 days to determine the strength properties of concrete.

\section{TEST AND RESULT}

\subsection{SLUMP FLOW TEST}

The main objective of this test is to determine the free flow of concrete and it is based on the slump cone test. This test will assess the filling ability of concrete and its resistance to segregation. Test results are shown in Table 3

TABLE 3 SLUMP FLOW TEST

\begin{tabular}{|l|l|l|}
\hline Mix & $\begin{array}{l}\text { Slump Flow } \\
\text { Test (mm) }\end{array}$ & $\begin{array}{l}\text { EFNARC } \\
\text { Guideliness }\end{array}$ \\
\hline SFRSCC1 & 705 & \multirow{2}{*}{$600-800$} \\
\cline { 1 - 2 } SFRSCC2 & 680 & \\
\cline { 1 - 2 } SFRSCC3 & 630 & \\
\cline { 1 - 2 } SFRSCC4 & 580 & \\
\hline
\end{tabular}

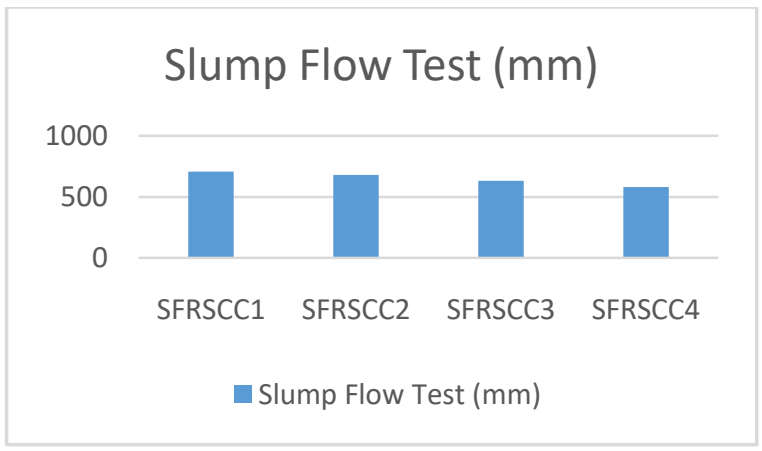

FIGURE1 SLUMP FLOW TEST

\subsection{V - FUNNEL TEST:}

The objective of this study is to determine the fillingability of concrete. The instrument consists of a $\mathrm{V}$ shaped funnel, it was filled by 12 liters of concrete and the time taken to drain the whole concrete is taken as the result of this test. The test results are shown in Table 4.

TABLE 4 V Funnel TEST

\begin{tabular}{|l|l|l|}
\hline Mix & $\begin{array}{l}\text { V Funnel Test } \\
(\mathrm{s})\end{array}$ & $\begin{array}{l}\text { EFNARC } \\
\text { Guideliness }\end{array}$ \\
\hline SFRSCC1 & 8 & 6 \\
\cline { 1 - 2 } SFRSCC2 & 9 & \\
\cline { 1 - 2 } SFRSCC3 & 11 & \\
\cline { 1 - 2 } SFRSCC4 & 9 & \\
\hline
\end{tabular}

TABLE 5 L BOX TEST

\begin{tabular}{|l|l|l|}
\hline Mix & $\begin{array}{l}\text { L }- \text { Box Test } \\
(\mathrm{h} 2 / \mathrm{h} 1)\end{array}$ & $\begin{array}{l}\text { EFNARC } \\
\text { Guideliness }\end{array}$ \\
\cline { 1 - 2 } SFRSCC1 & 0.85 & \multirow{2}{*}{$0.8-1.0$} \\
\cline { 1 - 1 } SFRSCC2 & 0.88 & \\
\cline { 1 - 2 } SFRSCC3 & 0.90 & \\
\hline SFRSCC4 & 0.91 & \\
\hline
\end{tabular}

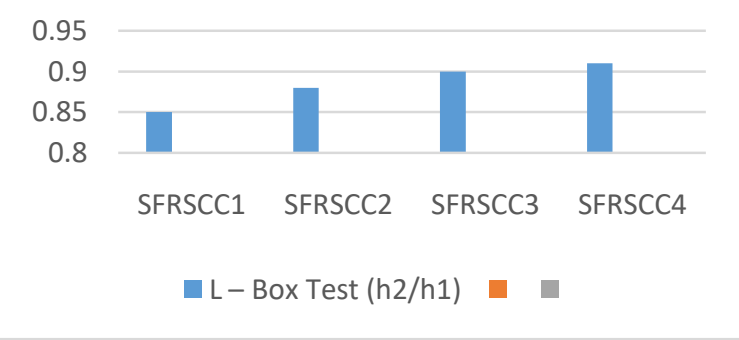

FIGURE3 L BOX TEST

\subsection{COMPRESSIVE STRENGTH TEST}

The SCC and STFRSCC specimens were casted in the shape of Cubical and it was tested in the compressive testing machine. The dimension of the cube is $100 \times 100 \times 100 \mathrm{~mm}$ and the compressive strength of the specimens were shown in Table 6.

TABLE 6 COMPRESSIVE STRENGTH TEST

\begin{tabular}{l|l|l|}
\hline Mix & $\begin{array}{l}\text { Compressive } \\
\text { strength 7 days } \\
\left(\mathrm{N} / \mathrm{mm}^{2}\right)\end{array}$ & $\begin{array}{l}\text { Compressive } \\
\text { strength28 } \\
\text { days }\left(\mathrm{N} / \mathrm{mm}^{2}\right)\end{array}$ \\
\hline SFRSCC1 & 9.5 & 15.3 \\
\hline SFRSCC2 & 11.5 & 18.6 \\
\hline
\end{tabular}




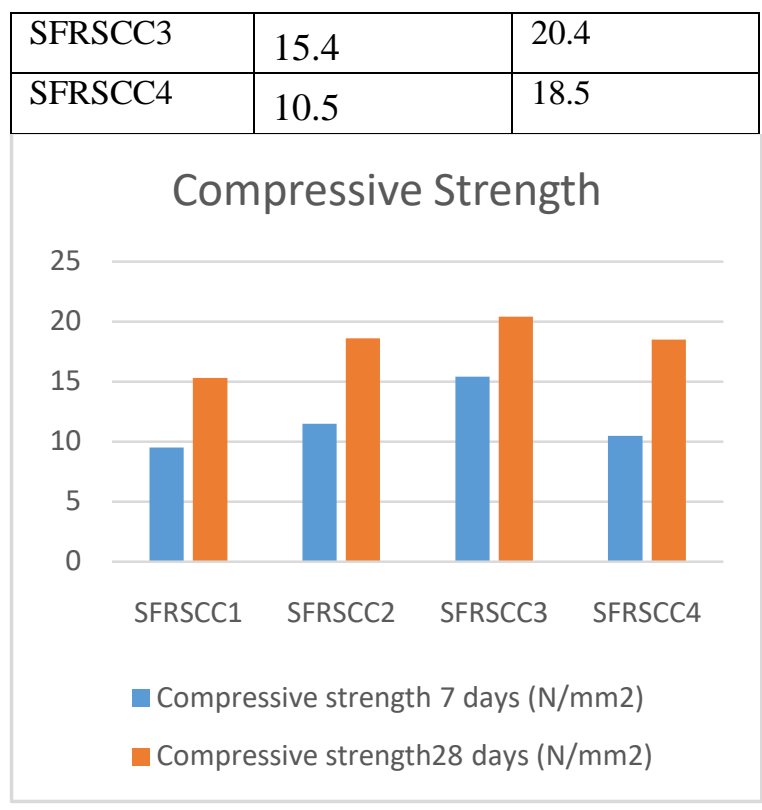

FIGURE 4 COMPRESSIVE STRENGTH TEST

\subsection{SPLITTING TENSILE STRENGTH}

The SCC and STFRSCC specimens were casted in the shape of cylinder and it was tested in compression testing machine of capacity $2000 \mathrm{KN}$. The dimension of the specimen is $100 \mathrm{~mm}$ diameter and $200 \mathrm{~mm}$ height.

The specimens are removed from water after curing and is then wiped and kept in compression testing machine. The cylinder is then subjected to loading and then the strength is found by applying load until the cylinder is subjected to failure. The test results are shown in Table 7.

TABLE 7 SPLIT TENSILE STRENGTH TEST

\begin{tabular}{|l|l|l|}
\hline Mix & $\begin{array}{l}\text { Split Tensile } \\
\text { strength 7 days } \\
\left(\mathrm{N} / \mathrm{mm}^{2}\right)\end{array}$ & $\begin{array}{l}\text { Split Tensile } \\
\text { strength28 } \\
\text { days }\left(\mathrm{N} / \mathrm{mm}^{2}\right)\end{array}$ \\
\hline SFRSCC1 & 1.76 & 2.6 \\
\hline SFRSCC2 & 1.91 & 2.9 \\
\hline SFRSCC3 & 2.1 & 3.1 \\
\hline SFRSCC4 & 1.8 & 2.8 \\
\hline
\end{tabular}

\section{Spli Tensile Strength}

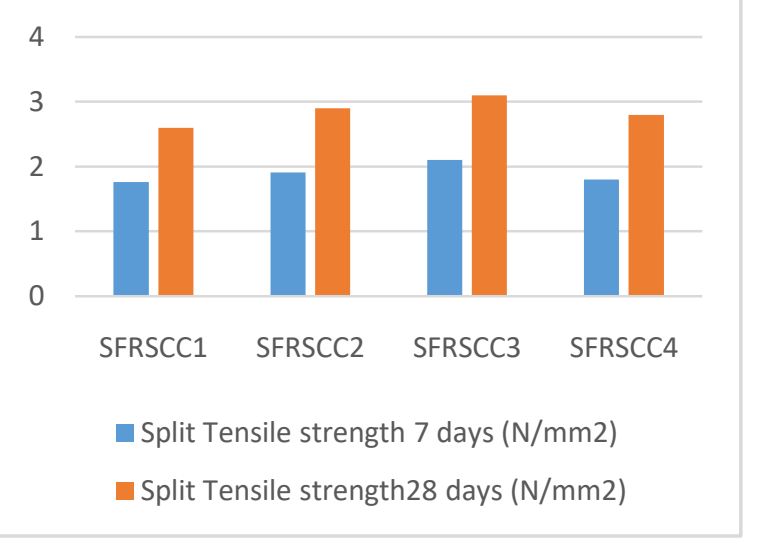

\section{FIGURE 5 SPLIT TENSILE STRENGTH TEST}

From the test and results it can be inferred that when the dosage increases more than 1 percent, the strength decreases significantly. But fibers can be effectively used to produce self- compacting concrete with high engineering properties.

\section{CONCULSION:}

Conclusion made from this study are,

All the self compacting specimens with the fiber were found to be in accordance with the EFNARC guide lines

The flowability of the fiber reinforced self-compacting concrete did not show any adverse effect however the workability was reduced.

Inclusion of fiber increased the compressive strength and tensile strength about $0.75 \%$ followed by a gradual reduction of strength.

\section{REFERENCES:}

1. Rafat Siddique, Gurwinder Kaur, Kunal, Strength and permeation properties of self-compacting concrete containing fly ash and hooked steel fibres, Construction and Building Materials 103 (2016)15-22.

2. Pratyush Kumar, Rahul Roy Pratyuh Kumar,Rahul Roy, Study and experimental investigation of flow and flexural properties of natural fiber reinforced self compacting concrete, International Conference on Smart Computing and Communications, (2017)78.

3. As'Ad, S., Gunawan, P., \&Alaydrus, M. S., Fresh State Behavior of Self Compacting ConcreteContaining Waste Material Fibres. Procedia Engineering, procedia engineering 14 (2011) 797-804.

4. Clifford A.O. Okeh, David W. Begg, Stephanie J. Barnett, Nikos Nanos, Behaviour of hybrid steel fibre reinforced self compacting concrete using innovative hooked-end steel fibres under tensile stress, Construction and Building Materials 202 (2019)753-761.

5. Cristina Frazao, Aires Camoes, Joaquim Barros, Delfina Goncalves, Durability of steel fiberreinforced self- compacting concrete, Construction and Building Materials 80 (2015)155-166.

6. Mohammad Ghasemi, Mohammad Reza Ghasemi, Seyed Roohollah Mousavi, Studying thefracture

7. parameters and size effect of steel fiber-reinforced selfcompacting concrete, construction and building materials 201 (2019) 447- 460.

8. Oldrich Svec, Giedrius Zirgulis, John E. Bolander, Henrik Stang, Influence of formworksurface on the

9. orientation of steel fibres within self-compacting concrete and on the mechanical properties of cast structural elements, Cement \& Concrete Composites 50 (2014) 60-72.

10. Sai Nitesh K.J.N, S. Venkateswara Rao, P. Rathish, An experimental investigation on torsional behaviorof

11. recycled aggregate based steel fiber reinforced self compacting concrete, journal of building engineering (2018).

12. Salem G. Nehmea, Roland Laszlob, Abdulkader El Mirc, Mechnical performance of steel fibrereinforced

13. self-compacting concrete in panels, Creative Construction Conference (2017) 19-22.

14. A.ChithambarGanesh,M.Muthukannan,M.Rajeswaran,T.Umash ankar,MariSelvam,Comparitivestudy on the behavior of Geopolymer concrete using Msand and conventional concrete exposed to elevated temperature, International Journal of Civil Enfineering and Technology, 9(11) (2018) pp -981-989.

\section{AUTHORS PROFILE}

Mr. A. Chithambar Ganesh completed his M.Tech in Structural

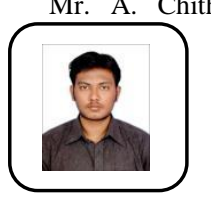
Engineering in VIT University, Vellore in the year 2015 He completed his Bachelor of Engineering under Anna University in the year 2012. He is working as Assistant Professor in Department of Civil Engineering at Kalasalingam University, Tamilnadu, India. His main thrust research areas are Geopolymer concrete and Fiber reinforced concrete.

Published By: 


\section{Effect of steel fibers over the Self Compacting Concrete}

Dr. Muthukannan M completed his Ph.D in Civil Engineering in Anna University, Chennai in the year 2010 He completed Master of Engineering in the field

of Transportation Engineering and Management in College of Engineering, Guindy, Chennai in the year 2004. He completed his Bachelor of Engineering under Madurai Kamarajar University in the year 2000. He is presently working as a Professor in Civil Engineering department at Kalasalingam University, Tamilnadu, India. He is guiding for many Ph.D scholars in the field of transporation engineering and computer applications in transportation network using graph theory. He has published various quality papers in the reputed journals. His main thrust research areas are transportation network design, transport management and travel demand management. 